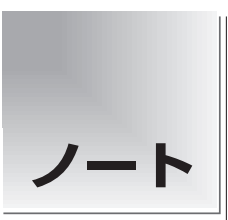
2010 年 11 論文受付 論文受理 2011年1月25日

Code No. 251

\section{マルチディテクタ CT におけるハイブリッド型 逐次近似画像再構成(iDose)アルゴリズムを用いた 低線量撮像時の冠動脈石灰化の定量評価： フィルタ補正逆投影法との比較}

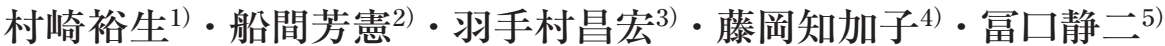

\begin{abstract}
1 ) 熊本大学大学院保健学教育部
2) 熊本大学大学院生命科学研究部先端生命医療科学部門医療技術科学講座医用理工学

3)熊本大学医学部附属病院医療技術部診療放射線技師部門

4) 広島大学病院診療支援部放射線部門

5) 熊本大学大学院生命科学研究部先端生命医療科学部門医療技術科学講座医用画像学
\end{abstract}

緒

Computed tomography $(\mathrm{CT})$ 装置を用いた Agatston スコアなどのカルシムスコアが冠動脈石疢化を検出・
定量するために導入されている。 カルシウムスコアが 使用される理由としては, 冠動脈の石灰化の程度と アテローム性動脈硬化の進行に相関性があるためで

\title{
Quantitative Evaluation of Calcium (content) in the Coronary Artery Using Hybrid Iterative Reconstruction (iDose) Algorithm on Low-dose 64-Detector CT: Comparison of iDose and Filtered Back Projection
}

\author{
Hiroo Murazaki, ${ }^{1)}$ Yoshinori Funama, ${ }^{2)}$ Masahiro Hatemura, ${ }^{3)}$ Chikako Fujioka, ${ }^{4)}$ and \\ Seiji Tomiguchi ${ }^{5}$ \\ 1) Graduate School of Health Sciences, Kumamoto University \\ 2) Department of Medical Physics, Faculty of Life Sciences, Kumamoto University \\ 3) Department of Radiology, Kumamoto University Hospital \\ 4) Department of Radiology, Hiroshima University Hospital \\ 5) Department of Medical Imaging, Faculty of Life Sciences, Kumamoto University
}

Received November 24, 2010; Revision accepted January 25, 2011 ; Code No. 251

\section{Summary}

To evaluate the usefulness of hybrid iterative reconstruction (iDose) for quantification of calcium content in the coronary artery on 64-detector computed tomography (CT), an anthropomorphic cardiac CT phantom containing cylinders with known calcium content was scanned at tube current-time products of 15 , 20, 25, and $50 \mathrm{mAs}$ using 64-detector CT. The images obtained at 15, 20, 25, and $50 \mathrm{mAs}$ were reconstructed using filtered back projection (FBP), and those at 15, 20, and $25 \mathrm{mAs}$ were also reconstructed using iDose. Then the volume and mass of the calcium content in the cylinders were calculated and compared with the true values. The Agatston score was also evaluated. The Agatston score and mass of calcium obtained at 50 mAs using FBP were 656.92 and $159.91 \mathrm{mg}$, respectively. In contrast, those obtained at $25 \mathrm{mAs}$ using iDose were 641.91 and $159.05 \mathrm{mg}$, respectively. No significant differences were found in the calcium measurements obtained using FBP and iDose. In addition, the Agatston score and mass of calcium obtained at $15 \mathrm{mAs}$ and $20 \mathrm{mAs}$ using iDose were not significantly different from those obtained at $25 \mathrm{mAs}$ with iDose. By using iDose, accurate quantification of calcium in the coronary artery can be achieved at $15 \mathrm{mAs}$ using 64-detector CT. The radiation dose can be significantly reduced in coronary artery calcium scoring without impairing the detection and quantification of coronary calcification.

Key words: coronary artery calcium (CAC), hybrid iterative reconstruction (iDose), dose reduction, filtered back projection (FBP), multidetector $C T$

別刷資料請求先：干 862-0976 熊本市九品寺 4-24-1 


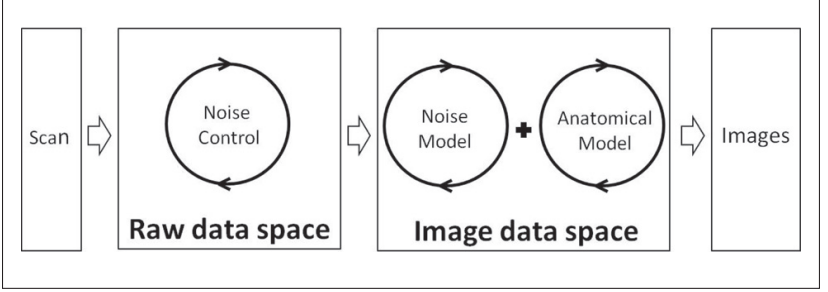

Fig. 1 Conceptual diagram of hybrid iterative reconstruction (iDose).

ある1,2).さらに，カルシウムスコアによって冠動脈疾 患が疑われる患者の冠動脈イベントのリスクを予測 することも行われている ${ }^{3 \sim 5)}$. カルシウムスコアは冠 動脈造影検查に比べて侵襲性が低く, 冠動脈病変の スクリーニングや以後の経過観察に有用である。一般 的にリスクの予測には定量值が利用され，これらは冠 動脈のカルシウム容積や重量などの計測および CT 值 を利用した Agatston スコアなどで評価されている6,7). これらを経過観察で使用する場合, 低線量での CT スキャンが望ましい。しかし，CT 検査においてス キャン線量と画像ノイズには密接な関係があり, 過度 の線量低減は画像ノイズを増加させ，冠動脈石灰化 の検出に影響を与える ${ }^{8)}$. Rutten $5^{9)}$ も低線量スキャ ンではノイズが増加するため冠動脈石灰化の評価に おいて定量性が低下すると報告している。特に,

Agatston スコアは最大 $\mathrm{CT}$ 值に基づいてスコア計算 を行っており，画像ノイズに強く影響を受ける ${ }^{10)}$.

最近, CT 検査における撮像線量の低減を目的に逐 次近似再構成法を応用した再構成法(iDose)が CT 像 の再構成に導入された。この新しい画像再構成アル ゴリズムは低線量で増加する画像ノイズを低減できる 特徵を持ち, filtered back projection(FBP)法の欠点を 補うものとして期待される。冠動脈石灰化の定量評 価において画像再構成にiDose 法を使用することで, 低線量でも従来通りの評価が可能と考えられる。

本研究の目的は，冠動脈石灰化の定量評価におい て, iDose 法による低線量での冠動脈石死化の定量 性を FBP 法と比較検討し, iDose 法の有用性を明ら かにすることである。

\section{1. 方 法}

\section{1-1 ハイブリッド型の逐次近似法（iDose）}

本研究ではノイズ低減の目的からハイブリッド型の 逐次近似法(iDose)を使用した ${ }^{11)}$. Fig. 1 にハイブリッ ド型逐次近似再構成法の概念図を示す。iDose 法は 最初, raw data space(生デー夕領域)において, サイ ノグラムの逐次近似計算によりノイズ成分を除去す る. 次に image data space(画像デー夕領域)におい て, 組織形状に関する情報と統計学的ノイズに関す

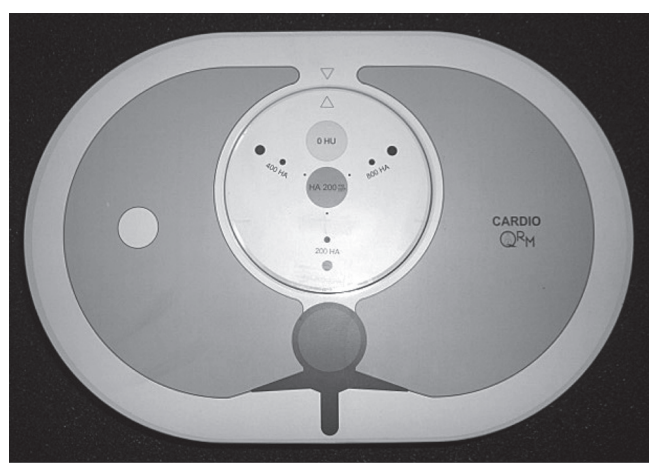

Fig. 2 Anthropomorphic phantom body with nine calcifications.

る情報を考慮して, 繰り返しノイズのコントロールが 行われる。これによって，低線量で発生するノイズお よびアーチファクトを軽減し，低線量での撮像を可能 にするものである.

\section{1-2 ファントム}

ファントムは Anthropomorphic cardiac CT phantom （QRM, Moehrendorf, Germany)を使用した(Fig. 2). ファントムのサイズは, 幅 $300 \mathrm{~mm}$, 高さ $200 \mathrm{~mm}$, 奥行き $100 \mathrm{~mm}$ である. このファントムは肺, 春椎, 軟部組織等価物質でできている。心臓の位置には, 容積とカルシウム密度が異なる円柱状の模擬冠動脈 石灰化を 9 力所に挿入されている。模擬冠動脈石死化 の直径はそれぞれ 1.0，3.0，5.0 mm で，カルシウム密 度は，それぞれのサイズで 200，400，800 mg HA/ $\mathrm{cm}^{3}$ である。また，模擬石灰化の総カルシウム重量は， $167.70 \mathrm{mg}$ である.

\section{1-3 撮像条件}

CT 装置は 64 列マルチディテクタ CT 装置(Brilliance 64, Philips Healthcare, Cleveland, Ohio)を使用 した。本実験において mAs 值は50 mAs を標準線量 とし，さらに $\mathrm{mAs}$ 值を 3 段階 $(15 ， 20 ， 25 \mathrm{mAs})$ に変 更し撮像した。撮像はそれぞれの $\mathrm{mAs}$ 值で 3 回行っ た。スキャンモードは step-and-shootモードで心電四 同期を行い, 心拍数は $60 \mathrm{bpm}$ を使用した。 また, コ リメーション $40 \times 0.625 \mathrm{~mm}$, 管電圧 $120 \mathrm{kV}$, 回転時 間 $0.42 \mathrm{~s}$ ，スキャン範囲 $100 \mathrm{~mm}$ とした。それぞれの 撮像条件における $\mathrm{CTDI}_{\mathrm{w}}$ は，15，20，25，50 mAs で それぞれ，1.1，1.4，1.8，3.5 mGy であった。

\section{1-4 画像再構成}

標準線量 $50 \mathrm{mAs}$ の収集データは，FBP 法を用い

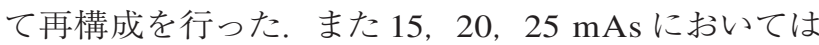
FBP 法およびiDose 法の両方で再構成を行った。 FBP 法およびiDose 法での再構成条件はスライス厚 
Table 1 Values of image noise using FBP and iDose reconstruction algorithms at different tube current- time products (mAs) and iDose levels

\begin{tabular}{cccccc}
\hline \hline & \multicolumn{5}{c}{ Image Noize (HU) } \\
\cline { 2 - 4 } mAs & FBP & $\begin{array}{c}\text { iDose } \\
\text { iDose level 50\% }\end{array}$ & $\begin{array}{c}\text { iDose } \\
\text { iDose level 60\% }\end{array}$ & $\begin{array}{c}\text { iDose } \\
\text { iDose level 70\% }\end{array}$ & $\begin{array}{c}\text { iDose } \\
\text { iDose level 80\% }\end{array}$ \\
\hline 50 & 15.4 & & & & \\
25 & 22.3 & 18.7 & 16.8 & 14.6 & 12.1 \\
20 & 25.6 & & 19.3 & 16.8 & 14.0 \\
15 & 27.7 & & & 18.3 & 15.4 \\
\hline
\end{tabular}

$2.5 \mathrm{~mm}$ ，マトリックスサイズ 512×512，FOV $220 \mathrm{mm,}$ 再構成関数 standard，心電図の R-R 間隔 $75 \%$ で，体 軸横断像を作成した.

iDose 法ではiDose level（\%)を変更することで，低 減した線量によるノイズの増加が補正可能であり, そ れに伴い線量レベルが改善される。線量レベル(dose level)は以下の式により計算される.

dose level $=\frac{100-\text { dose reduction }(\%)}{100} \times \frac{100}{100-\text { iDose level }(\%)} \times 100 \%$

例えば，25 mAsにおいてはiDose levelを50, $60 ， 70,80 \%$ と設定した場合， $50 \mathrm{mAs}$ の $\mathrm{CTDI}_{\mathrm{w}}$ と 比較して $100,125,167,250 \%$ の線量レベルとな り,この改善された線量レベルをもとに画像ノイズも 改善される。今回の場合, $50 \mathrm{mAs} の 100 \%$ 線量に相 当するiDose levelのメーカ推奨值は $15 \mathrm{mAs}$ で $70 \%, 20 \mathrm{mAs}$ で 60\%, $25 \mathrm{mAs}$ で50\%であった.

\section{1-5 検討方法}

データ収集後, すべての再構成画像は CT ワーク ステーション (extended brilliance workspace (EBW)) に転送し Agatstonスコア，カルシウム容積，および カルシウム重量の算出を行った. Agatstonスコアの 定義はスライス厚 $3 \mathrm{~mm}$ であり， $2.5 \mathrm{~mm}$ のスライス 厚から $3 \mathrm{~mm}$ のスライス厚に正規化して表示した。 カ ルシウム重量に関しては，各サイズにおける模擬石 灰化の重量も測定した。閾值設定はワークステーショ ン上, Agatston スコアで $130 \mathrm{HU}$, カルシウム容積, カルシウム重量においてはカルシウム密度 $100 \mathrm{mg}$ $\mathrm{HA} / \mathrm{cm}^{3}$ と自動で設定される.

カルシウム重量の計算はカルシウム容積にカルシ ウム密度を乗じて求められる。 カルシウム密度はワー クステーション内に密度に対する CT 值が事前に設定 されており，測定した CT 值の計算から変換される.

すべての再構成画像について画像ノイズ (CT 值の 標準偏差)の測定を行った。ノイズ值は，円形関心領 域 $\left(132 \mathrm{~mm}^{2}\right)$ を水等価物質の中央部に配置し測定を
行った. 3 回のスキャンから得られた画像をそれぞれ 測定し平均值を結果として表示した。ただし，関心 領域のサイズ，位置はすべての測定で同じになるよう に設定した。

Agatston スコア, カルシウム容積およびカルシウム 重量の変動係数 $(\mathrm{CV})$ は平均值と標準偏差から以下の 式にて計算した。

$$
\mathrm{CV}=\frac{\text { 標準偏差 }}{\text { 平均值 }} \times 100 \%
$$

また, カルシウム重量に関しては測定值 $($ 容積 $\times$ カ ルシウム密度) と真值との誤差を calcium mass error (\%)とし算出し評価した.

calcium mass error $=\left|\frac{\text { measured calcium mass }- \text { physical calcium mass }}{\text { physical calcium mass }}\right| \times 100 \%$

\section{1-6 統計解析}

Agatston スコア, カルシウム容積, カルシウム重量 における有意差検定を行うため，ノンパラメトリック の多重比較法であるスティールの検定を使用した。 $50 \mathrm{mAs}(\mathrm{FBP})$ によって得られたスコアをコントロール とした。統計学的な有意水準は $P<0.05$ とした。

\section{2. 結 果}

\section{2-1 画像ノイズ}

Table 1 に FBP 法と iDose 法に関して mAs 值を変 化させた場合の画像ノイズ值を示すＦBP法の場 合, 画像ノイズは $15,20,25,50 \mathrm{mAs}$ でそれぞれ, 27.7, 25.6, 22.3, 15.4 HUとなった. mAs が減少す るにつれて, 画像ノイズは増加する傾向にあった。 FBP 法とiDose 法を比較した場合, 同じ mAsでも iDose 法を使用することによって画像ノイズは減少し た。 また, iDose levelの増加に対して，画像ノイズは 減少する傾向にあった. $50 \mathrm{mAs}$ と同等の画像ノイズ に改善するために，15 mAs(iDose level 70\%), 20 mAs(iDose level 60\%), 25 mAs(iDose level 50\%)で レベルを決定したが，その際の画像ノイズはそれぞ 
Table 2 Mean value and coefficient of variation (CV) for Agatston score, total volume, and total mass of calcium. The same image noise level was seen at $50 \mathrm{mAs}$ using FBP and 15, 20, and $25 \mathrm{mAs}$ using iDose.

\begin{tabular}{|c|c|c|c|c|}
\hline & \multicolumn{4}{|c|}{ Tube current-time product } \\
\hline & $\begin{array}{l}50 \\
\text { FBP }\end{array}$ & $\begin{array}{c}25 \\
\text { iDose level } 50 \%\end{array}$ & $\begin{array}{c}20 \\
\text { iDose level } 60 \%\end{array}$ & $\begin{array}{c}15 \\
\text { iDose level } 70 \%\end{array}$ \\
\hline \multicolumn{5}{|c|}{ Agatston score } \\
\hline Mean & 656.92 & 641.91 & 663.08 & 636.26 \\
\hline $\mathrm{CV}(\%)$ & 1.80 & 3.05 & 0.53 & 1.59 \\
\hline \multicolumn{5}{|l|}{ Total volume } \\
\hline Mean $\left(\mathrm{mm}^{3}\right)$ & 605.29 & 603.51 & 611.75 & 591.59 \\
\hline CV $(\%)$ & 1.04 & 2.11 & 2.11 & 1.96 \\
\hline \multicolumn{5}{|l|}{ Total mass } \\
\hline Mean (mg) & 159.91 & 159.05 & 162.97 & 159.59 \\
\hline CV $(\%)$ & 1.58 & 2.57 & 1.25 & 2.93 \\
\hline
\end{tabular}

Value shows a no statistical significance between scans obtained with $50 \mathrm{mAs}$ (FBP) and scans obtained with iDose $(P>0.05)$.

Table 3 Mean value and coefficient of variation for Agatston score, total volume, and total mass of calcium. Different image noise levels were seen at 50 mAs using FBP and 20 mAs using iDose.

\begin{tabular}{|c|c|c|c|c|}
\hline & \multirow[b]{2}{*}{$50 \mathrm{mAs}$ FBP } & \multicolumn{3}{|c|}{$20 \mathrm{mAs}$} \\
\hline & & iDose level $60 \%$ & iDose level 70\% & iDose level $80 \%$ \\
\hline \multicolumn{5}{|c|}{ Agatston score } \\
\hline Mean & 656.92 & 663.08 & 660.36 & 658.36 \\
\hline CV $(\%)$ & 1.80 & 0.53 & 0.48 & 0.67 \\
\hline \multicolumn{5}{|l|}{ Total volume } \\
\hline Mean $\left(\mathrm{mm}^{3}\right)$ & 605.29 & 611.75 & 599.90 & 597.75 \\
\hline CV $(\%)$ & 1.04 & 2.11 & 2.47 & 2.75 \\
\hline \multicolumn{5}{|l|}{ Total mass } \\
\hline Mean (mg) & 159.91 & 162.97 & 162.24 & 162.04 \\
\hline CV (\%) & 1.58 & 1.25 & 1.10 & 1.27 \\
\hline
\end{tabular}

Value shows a no statistical significance between scans obtained with $50 \mathrm{mAs}$ (FBP) and scans obtained with iDose $(P>0.05)$.

れ，18.3，19.3，18.7 HU となりほほほ同等であった。 しかし, 50 mAs(FBP)の画像ノイズと比較するとやや 高い傾向にあった。

\section{2-2ノイズが同等の場合におけるカルシウム定} 量値の比較

Table 2 に 50 mAs (FBP)に対し, 画像ノイズレベル が同等である 15，20，25 mAs(iDose)の Agatston ス コア, カルシウム容積および重量の平均值と CV を示 す. Agatston スコアおよびカルシウム容積において, 線量を $15 \mathrm{mAs}$ まで低減し, iDose levelを $70 \%$ と大 きくすると $50 \mathrm{mAs}(\mathrm{FBP})$ に比べて定量值が低下する 傾向がみられ, Agatston スコアは $3.1 \%(P>0.05)$, カ ルシウム容積で $2.3 \%(P>0.05)$ 低下した。 しかし, カ ルシウム重量においては, 15 mAs(iDose level 70\%) でも $50 \mathrm{mAs}$ の場合と同等の值が得られた $(P>0.05)$.
その他の定量值も同様に $50 \mathrm{mAs}(\mathrm{FBP})$ に対し有意差 はみられなかった $(P>0.05)$. 変動係数は, 線量の低 減率やiDose level には関係せず, 一定であった。

\section{2-3 iDose level の定量值への影響}

Table 3 は 20 mAs での iDose levelの違いによるカ ルシウム定量值の比較である. Agatstonスコア, カ ルシウム容積および重量のすべてにおいて, iDose level を大きくすると, スコアは若干減少する傾向で あった。しかし，スコアは減少するものの $50 \mathrm{mAs}$ $(\mathrm{FBP})$ に対し有意差はみられなかった $(P>0.05)$. 変動 係数は, iDose levelの大きさによらずすべての定量 值において同程度であった。

\section{2-4 カルシウム重量}

Table 4 に $50 \mathrm{mAs}(\mathrm{FBP})$ および $20 \mathrm{mAs}$ (iDose) で 
Table 4 Comparison of measured calcium mass with physical calcium mass obtained at $50 \mathrm{mAs}$ using FBP and at $20 \mathrm{mAs}$ using iDose

\begin{tabular}{|c|c|c|c|c|c|}
\hline \multirow{2}{*}{$\begin{array}{c}\text { Calcium cylinder } \\
\text { diameter and } \\
\text { density }\left(\mathrm{mg} \mathrm{HA} / \mathrm{cm}^{3}\right)\end{array}$} & \multirow{2}{*}{$\begin{array}{l}\text { Physical calcium } \\
\text { mass }(\mathrm{mg})\end{array}$} & \multicolumn{4}{|c|}{ Measured calcium mass (mg) } \\
\hline & & $\begin{array}{l}50 \mathrm{mAs} \\
\text { FBP }\end{array}$ & $\begin{array}{c}20 \text { mAs } \\
\text { iDose level } 60 \%\end{array}$ & $\begin{array}{c}20 \mathrm{mAs} \\
\text { iDose level 70\% }\end{array}$ & $\begin{array}{c}20 \mathrm{mAs} \\
\text { iDose level } 80 \%\end{array}$ \\
\hline Total & 167.70 & 159.91 & 162.97 & 162.24 & 162.04 \\
\hline \multicolumn{6}{|l|}{$5-\mathrm{mm} \phi$} \\
\hline 800 & 78.50 & 85.03 & 86.53 & 86.34 & 86.40 \\
\hline 400 & 39.30 & 36.61 & 36.40 & 36.15 & 36.06 \\
\hline 200 & 19.60 & 13.44 & 13.43 & 13.23 & 13.12 \\
\hline \multicolumn{6}{|l|}{ 3-mm $\phi$} \\
\hline 800 & 17.00 & 15.71 & 16.67 & 16.68 & 16.59 \\
\hline 400 & 8.50 & 6.59 & 7.34 & 7.29 & 7.32 \\
\hline 200 & 4.20 & 2.13 & 2.23 & 2.19 & 2.19 \\
\hline \multicolumn{6}{|l|}{$1-\mathrm{mm} \phi$} \\
\hline 800 & 0.60 & 0.41 & 0.55 & 0.54 & 0.54 \\
\hline
\end{tabular}

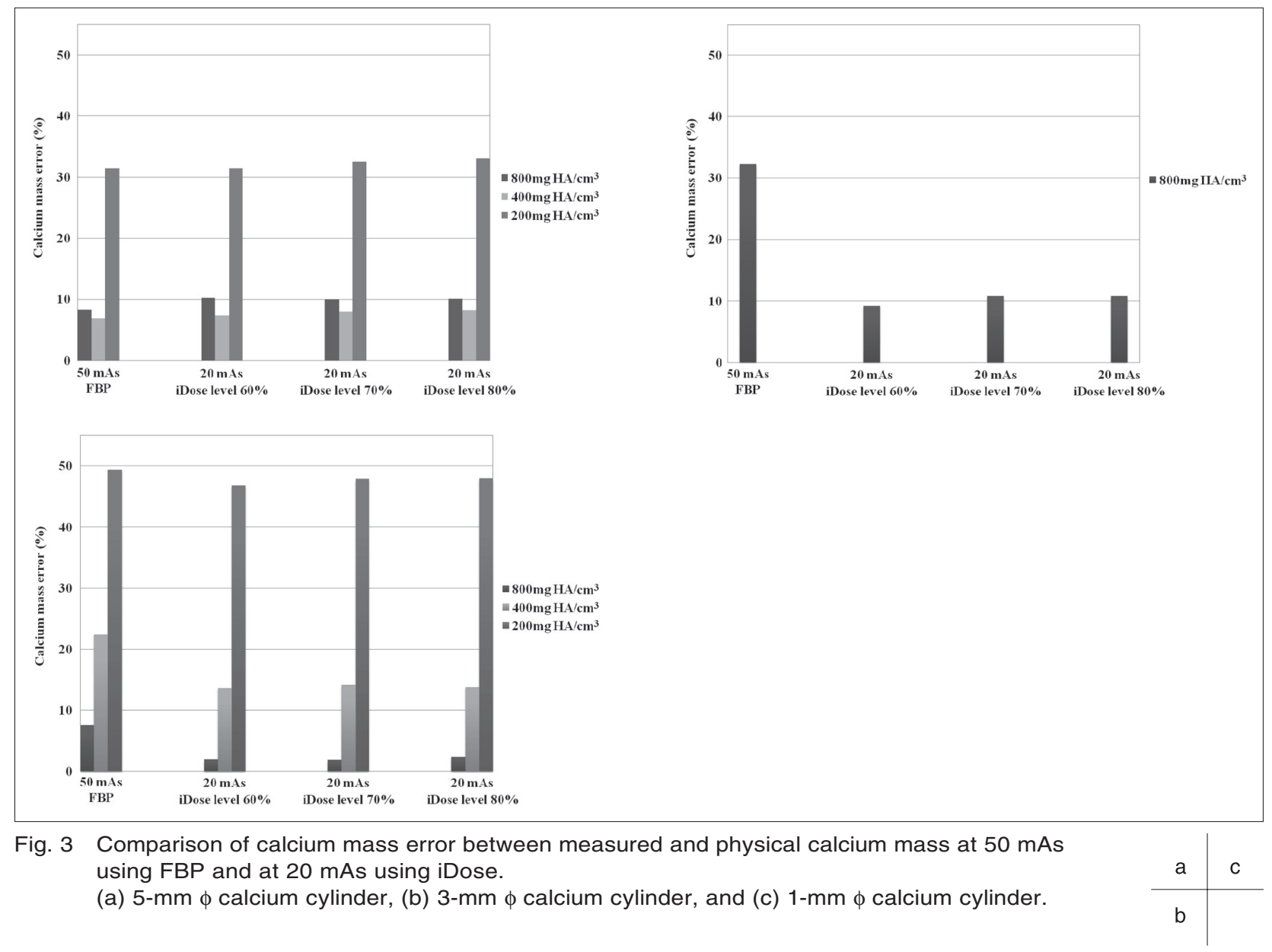

得られた，各サイズにおける模擬石灰化部のカルシ ウム重量を示す。直径 $5 \mathrm{~mm}$ でカルシウム密度 800 $\mathrm{mg} \mathrm{HA} / \mathrm{cm}^{3}$ の 部 位では, $50 \mathrm{mAs}(\mathrm{FBP}), 20 \mathrm{mAs}$ (iDose level $60 \%$ ), 20 mAs(iDose level $70 \%$ ), 20 mAs(iDose level $80 \%$ ) で，それぞれ85.03, 86.53, $86.34,86.40 \mathrm{mg}$ と真值の $78.5 \mathrm{mg}$ に対して高值を示 した。しかし，それ以外の模擬石灰化部では，50
$\mathrm{mAs}(\mathrm{FBP}), 20 \mathrm{mAs}(\mathrm{iDose})$ ともに真值より低值で あった。

Fig. 3a〜c に $50 \mathrm{mAs}(\mathrm{FBP}), 20 \mathrm{mAs}($ iDose) による カルシウム重量の測定值と真值の誤差を示す。直径 5 $\mathrm{mm}$ の部位では，カルシウム密度にかかわらず50 $\mathrm{mAs}(\mathrm{FBP}), 20 \mathrm{mAs}(\mathrm{iDose})$ につてカルシウム重量 の誤差に差はなかった(Fig. 3a). 直径 $3 \mathrm{~mm}$ の部位で 
は, カルシウム密度が $400,800 \mathrm{mg} \mathrm{HA} / \mathrm{cm}^{3}$ の場合, $50 \mathrm{mAs}(\mathrm{FBP})$ に対し $20 \mathrm{mAs}($ iDose $)$ で誤差は小さく, それぞれ約 $5.0 \%, 8.0 \%$ であった。しかし，カルシウ ム密度が $200 \mathrm{mg} \mathrm{HA} / \mathrm{cm}^{3}$ の部位では, 50mAs(FBP) と $20 \mathrm{mAs}($ iDose $) の$ 誤差は同等であった(Fig. 3b). 直 径 $1 \mathrm{~mm}$ でカルシウム密度が $800 \mathrm{mg} \mathrm{HA} / \mathrm{cm}^{3}$ の部位 では, $50 \mathrm{mAs}(\mathrm{FBP}) に$ 対し $20 \mathrm{mAs}$ (iDose)では誤差 は約 22\%小さい值であった(Fig. 3c).

\section{3. 考 察}

\section{3-1 線量低減と iDose level}

本研究では, 線量を低減しiDose 法を使用するこ とでFBP法と低線量画像に対してメーカ推奨值で iDose level を変化させノイズ量を同等とした場合，す べての定量值において FBP 法と同等の結果が得られ た. 特にカルシウム重量については, Agatston スコア やカルシウム容積に対し, より安定した值が得られた (Table 2). iDose level を変更した場合, すべての定 量值において, iDose level を高くするにつれて定量 值が減少する傾向がみられた(Table 3)。これは, iDose level を大きく設定したことで，画像ノイズだけ でなくカルシウム部分の信号まで低下したためである と考える。特に, Agatstonスコアに関しては, 計算に 最大 CT 值を使用している。 そのためスコアは画像ノ イズの影響を強く受け, iDose levelの増加にともない カルシウム部分の最大 CT 值が低下し, Agatston ス コアが低い值を示したものと考える。iDose level と各 定量值を考慮すると, 画像ノイズの過度の低減を意 識してiDose levelの設定を大きくすると值自体も低 下するため, 今回の結果から線量を低減するには線 量低減前の基準線量とノイズが同程度となるような iDose level の設定で十分であると考える.

\section{3-2 石灰化の大きさとカルシウム密度の影響}

今回の使用したファントムにおいて, 直径 $1 \mathrm{~mm}$ で カルシウム密度が $200,400 \mathrm{mg} \mathrm{HA} / \mathrm{cm}^{3}$ の模擬石灰 化部は，検出することはできなかった。これは部分容 積効果により模擬石灰化部の CT 值が閾值 (130 HU または $\left.100 \mathrm{mg} \mathrm{HA} / \mathrm{cm}^{3}\right)$ より常に小さかったためと考 えられる。本研究に抏て, iDose 法を使用し画像ノ イズを補正した場合でも，本来閾值以下のカルシウ ムを検出することは難しくFBP 法を用いた場合と同 様の結果が得られている。したがって, iDose 法を使 用しても非常に小さい石灰化でカルシウム密度も低 いものの検出は困難であることが示唆される。一方, 直径 $3 \mathrm{~mm}$ でカルシウム密度が $400,800 \mathrm{mg} \mathrm{HA} / \mathrm{cm}^{3}$ の部および，直径 $1 \mathrm{~mm}$ でもカルシウム密度が $800 \mathrm{mg}$ $\mathrm{HA} / \mathrm{cm}^{3}$ の部は iDose 法を使用することで, FBP 法と
比較し真值に近い測定值の算出が可能であった(Fig. $3 \mathrm{~b} \sim \mathrm{c})$. このようにカルシウムの CT 值が閾值を超え る場合にはiDose 法を使用することで定量性は向上 する.

\section{3-3 臨床応用の可能性について}

冠動脈石死化の定量評価は冠動脈疾患無症候性患 者に対する心事故のリスク評価や非典型的な胸部症 状を有する患者の冠動脈疾患のスクリーニングとし て推奨されている6). Budoff ら ${ }^{12)}$ は無症候者と Agatston スコア別の累積生存曲線について報告し，スコ アの増加とともに生存率が低下し，1000を超える場 合は追跡期間 12 年で生存率は $76.9 \%$ に低下すると述 ベている. また, Rumberger ら ${ }^{7)}$ はスコア $=0$ (very low risk), スコア>0〜10(low risk), スコア>10〜100 (moderate risk), スコア>100 400 (moderately high risk)，スコア $>400$ (high risk)のようなリスクの層別化 が可能と報告している。冠動脈石灰化の定量評価に 対する精度はファントムのスキャンとは異なり臨床で は, 心臓のモーションアーチファクトの影響から再現 性はファントムと比較して，さらに低下する13〜16). McCollough $5^{10)}$ の報告では, 同一患者・装置におけ る Agatston スコアのパーセント誤差(2 值の差をその 平均值で除したもの)は 19～37\%程度であると述べて いる。また，心臓のモーションアーチファクトの影響 によりカルシウムスコアが上昇することも知られてい る ${ }^{17)}$. 本研究では線量低減を行い, iDose 法を使用し た場合，すべての定量值で值の変動係数はおよそ3\% 以下であった。したがって，iDose 法を使用した場合 のモーションアーチファクトの影響については今後の 課題であるが，臨床でも十分に使用可能と考える.

われわれの研究における制限は，今回，どのスラ イス位置でも同じような X 線吸収であるファントムを 使用した。ただし，画像ノイズはスキャンパラメータ だけでなくスキャンされる解剖学的領域にも依存す る. Raggi ら ${ }^{18)} は$, electron-beam CTにおいて, 心基 部に比べて心尖部の方が, 画像ノイズが増加すると 報告している。これは，肝臓や横隔膜で X 線吸収が 大きいためである。われわれの検討ではこの影響ま で含んだ結果を示すことは困難であった。臨床にお いては, この潜在的なノイズの変化が低線量スキャ ンにおいて，カルシウム定量值に影響してくる可能 性もあるが, iDose 法を使用することで解決可能であ ると期待される。また, iDose levelの設定に伴う Agatston スコアの変化は, 画像ノイズの影響および iDose 法による処理の影響が複合して結果に反映さ れ，分けて評価を行うことは難しい。しかし，今後検 討する必要があると考える。 


\section{4. 結 語}

本研究では, カルシウムスコアの CT スキャンにお いて, iDose 法を併用することで線量低減およびスコ アの改善について検討を行った. カルシウムスコアに iDose を併用することにより，従来より使用されてい る FBP と比較し, スキャン線量の低減が可能である
とともにカルシウムスコアの改善もみられた。 カルシ ウムスコアを目的とした CT スキャンにiDoseを併用 することで，ファントム実験においては少なくとも $50 \%$ の線量低減が可能であり, 臨床においてもカル シウムスコアを維持した状態で更なるスキャン線量の 低減が可能であると期待される。

\section{参考文献}

1) Agatston AS, Janowitz WR, Hildner FJ, et al. Quantification of coronary artery calcium using ultrafast computed tomography. J Am Coll Cardiol 1990; 15(4): 827-832.

2) Rumberger JA, Simons DB, Fitzpatrick LA, et al. Coronary artery calcium area by electron-beam computed tomography and coronary atherosclerotic plaque area. A histopathologic correlative study. Circulation 1995; 92(8): 2157-2162.

3) Arad Y, Goodman KJ, Roth M, et al. Coronary calcification, coronary disease risk factors, C-reactive protein, and atherosclerotic cardiovascular disease events: the St. Francis Heart Study. J Am Coll Cardiol 2005; 46(1): 158-165.

4) Greenland P, LaBree L, Azen SP, et al. Coronary artery calcium score combined with Framingham score for risk prediction in asymptomatic individuals. JAMA 2004; 291(2): 210-215.

5) Shaw LJ, Raggi P, Schisterman E, et al. Prognostic value of cardiac risk factors and coronary artery calcium screening for all-cause mortality. Radiology 2003; 228(3): 826-833.

6) Greenland P, Bonow RO, Brundage BH, et al. ACCF/AHA 2007 clinical expert consensus document on coronary artery calcium scoring by computed tomography in global cardiovascular risk assessment and in evaluation of patients with chest pain: a report of the American College of Cardiology Foundation Clinical Expert Consensus Task Force (ACCF/AHA Writing Committee to Update the 2000 Expert Consensus Document on Electron Beam Computed Tomography) developed in collaboration with the Society of Atherosclerosis Imaging and Prevention and the Society of Cardiovascular Computed Tomography. J Am Coll Cardiol 2007; 49(3): 378-402.

7) Rumberger JA, Brundage BH, Rader DJ, et al. Electron beam computed tomographic coronary calcium scanning: a review and guidelines for use in asymptomatic persons. Mayo Clin Proc 1999; 74(3): 243-252.

8) Bielak LF, Kaufmann RB, Moll PP, et al. Small lesions in the heart identified at electron beam $\mathrm{CT}$ : calcification or noise? Radiology 1994; 192(3): 631-636.

9) Rutten A, Isgum I, Prokop M. Coronary calcification: effect of small variation of scan starting position on Agatston, volume, and mass scores. Radiology 2008; 246(1): 90-98.

10) McCollough $\mathrm{CH}$, Ulzheimer $\mathrm{S}$, Halliburton SS, et al. Coronary artery calcium: a multi-institutional, multimanufacturer international standard for quantification at cardiac CT. Radiology 2007; 243(2): 527-538.

11）菅原 崇. iDose- 最大 $80 \%$ の被ばく低減を実現する画像 再構成法. Innervision 2010; 25(10):68-69.

12) Budoff MJ, Shaw LJ, Liu ST, et al. Long-term prognosis associated with coronary calcification: observations from a registry of 25,253 patients. J Am Coll Cardiol 2007; 49(18): 1860-1870.

13) Detrano RC, Anderson M, Nelson J, et al. Coronary calcium measurements: effect of CT scanner type and calcium measure on rescan reproducibility-MESA study. Radiology 2005; 236(2): 477-484.

14) Hong C, Bae KT, Pilgram TK, et al. Coronary artery calcium quantification at multi-detector row CT: influence of heart rate and measurement methods on interacquisition variability initial experience. Radiology 2003; 228(1): 95-100.

15) Ulzheimer S, Kalender WA. Assessment of calcium scoring performance in cardiac computed tomography. Eur Radiol 2003; 13(3): 484-497.

16) Wang S, Detrano RC, Secci A, et al. Detection of coronary calcification with electron-beam computed tomography: evaluation of interexamination reproducibility and comparison of three image-acquisition protocols. Am Heart J 1996; 132(3): 550-558.

17) Brown SJ, Hayball MP, Coulden RA. Impact of motion artefact on the measurement of coronary calcium score. Br J Radiol 2000; 73(873): 956-962.

18) Raggi P, Callister TQ, Cooil B. Calcium scoring of the coronary artery by electron beam CT: how to apply an individual attenuation threshold. AJR Am J Roentgenol 2002; 178(2): 497-502.

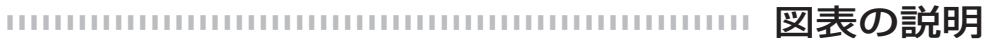

Fig. 1 ハイブリッド型逐次近似再構成法(iDose)の概念図

Fig. 29 つの模擬冠動脈石灰化が入った模擬人体ファントム

Fig. $350 \mathrm{mAs}(\mathrm{FBP})$ と $20 \mathrm{mAs}(\mathrm{iDose})$ における測定值と真值間のカルシウム重量誤差の比較

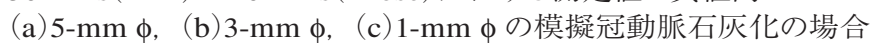

Table 1 異なる mAs と iDose levelに打り FBP 法とiDose 法を使用した場合の画像ノイズ

Table 2 Agatston スコア, 総カルシウム容積および重量の平均值および変動係数

$50 \mathrm{mAs}(\mathrm{FBP})$ と 15, 20, $25 \mathrm{mAs}$ (iDose)間で等しいノイズレベルの場合.

Table 3 Agatston スコア, 総カルシウム容積および重量の平均值および変動係数 $50 \mathrm{mAs}(\mathrm{FBP})$ と $20 \mathrm{mAs}$ (iDose)間で異なる画像ノイズレベルの場合.

Table 450 mAs (FBP) と 20 mAs(iDose)で得られたカルシウム重量の測定值と真值の比較 